\title{
Assessment of water management technology on rice productivity on iron poisoning rice fields in Jambi
}

\author{
Busyra B. Saidi ${ }^{1}$, Jon Hendri ${ }^{1}$, and Suratman ${ }^{2}$ \\ ${ }^{1}$ Asessment Institute for Agricultural Technology of Jambi Province \\ ${ }^{2}$ Center for Research and Development of Agricultural Land Resources Bogor
}

\begin{abstract}
The study of "Water Management Technology Against Rice Productivity in New wetland Openings of Iron Poisoning Rice" was carried out in Betara District, West Tanjung Jabung Regency from April to October 2018. The research used a randomized block design (RBD) with four replications. The treatment consisted of four intervals of providing irrigation water, namely; (CI) Continuous irrigation, (DWI1) Dry wet irrigation (DWI) 5 day intervals from 1 week to 7 weeks after planting (WAP), (DWI2) DWI with 7 days interval from 1 week to 7 WAP, and (DWI3) DWI 7 days interval from 1 WAP to 65 days after planting (DAP) and inundation 15 days before harvest (DBH). Fertilizer recommendations based on soil nutrient status as a result of analysis with the Swamp Soil Test Kit (SSTK), namely 1.0 tonnes / ha lime, $75 \mathrm{~kg} \mathrm{ha}^{-1}$ Urea (basic fertilizer) then based on LCC, $150 \mathrm{~kg} \mathrm{ha}^{-1} \mathrm{SP} 36$ (given entirely at planting time) and $125 \mathrm{~kg} \mathrm{ha}^{-1} \mathrm{KCl}(1 / 3$ part at planting, $1 / 3$ part at 3-4 WAP and 1/3 part at plant age 6-7 WAP. Result showed the water supply interval significantly affects the growth and production of rice, the highest yield is obtained with a 7 day water supply interval from 1 to 7 WAP, with rice production 4,29 tonnes $\mathrm{ha}^{-1}$, whereas with the provision of water from 1 WAP until just before harvest, the rice production was 2.06 tonnes ha ${ }^{-1}$.
\end{abstract}

\section{Introduction}

Increasing population from year to year has implications for the need for food which is also increasing. On the other hand, conversion of productive paddy fields to non-agricultural land is unavoidable, especially in Java. This encourages the government to look for potential land that has not been used optimally, one of the efforts is by expanding the planting area and printing new rice fields which are mostly directed at sub-optimal lands outside Java [1,2].

During a period of 2006-2014 the Ministry of Agriculture has printed a new rice field area of 431,000 ha. In Jambi Province it is 2,500 ha, in Tanjung Jabung Barat it is 2,364 ha [3]. Generally, newly opened paddy fields outside Java on marginal lands, especially low

* Corresponding author: sidibusyra@gmail.com 
fertility and acid reactions (Inceptisols, and Histosols), so that to increase rice productivity, they will face problems with physicochemical changes due to flooding, including iron or manganese poisoning [4].

In terms of soil fertility, inundation or rice fields in newly opened rice fields will result in changes in chemical compounds due to biogeochemical transformations carried out by microbes. One of the important effects is ferrous iron $\left(\mathrm{Fe}^{2+}\right)$ poisoning. Iron compounds which in dry soil conditions are at the oxidative level of $\mathrm{Fe}+3$ will be reduced to $\mathrm{Fe}^{2+}$ which is toxic to plants. The concentration of ferrous iron after about 3-4 weeks of inundation increases to $600 \mathrm{ppm}$, in this condition Fe levels can be toxic to rice plants. This iron poisoning results in low production, even plants do not produce. In addition to iron poisoning, in newly opened rice fields also show a lack of $\mathrm{P}, \mathrm{K}, \mathrm{Ca}, \mathrm{Mg}$ and $\mathrm{Zn}$ nutrients, soil $\mathrm{pH}$ can reach 3-7 [1,5,6].

Symptoms of iron poisoning in rice only occur under specific conditions, namely in flooded conditions. Reduction conditions in flooded rice fields show symptoms of iron poisoning through dissolving all forms of $\mathrm{Fe}$ into soluble forms $\left(\mathrm{Fe}^{+2}\right)$ involving microbial solvents [7]. Fe poisoning in rice occurs because soil with high Fe content in flooded conditions will dissolve iron as $\mathrm{Fe}^{2+}$ with high levels. The solubility can be $6,000-8,000 \mathrm{mg}$ $\mathrm{kg}^{-1}$ [8]. At concentrations of $\mathrm{Fe}^{2+} 1,000-2,000 \mathrm{mg} \mathrm{kg}^{-1}$ can affect the production of lowland rice [9]. The critical limit of Fe stress that can be tolerated by rice plants is $250-500 \mathrm{mg} \mathrm{kg}^{-}$ ${ }^{1}$. Furthermore, yield reduction due to Fe poisoning ranges from $50 \%$ [10].

Swamp in Betara sub-district is not affected by tides. The source of water in the swamp comes from rainfall, both local and from the surrounding environment. Lebak swamp rice field with high Fe content in Betara sub-district comes from alluvium deposits [11].

Iron poisoning is a major constraint in rice production in the tropics and subtropics, where it is estimated that around 4 million ha of land are affected by iron poisoning which can reduce rice yields by $30-60 \%$ [12], iron poisoning in heavily attacked rice plants resulted in very poor growth, tillers did not grow so that the results obtained were very low and could even lead to crop failure [13].

Symptoms of iron poisoning in rice only occur under specific conditions, namely in flooded conditions. Reduction conditions in flooded rice fields show symptoms of iron poisoning through dissolving all forms of $\mathrm{Fe}$ into soluble forms $\left(\mathrm{Fe}^{+2}\right)$ involving microbial solvents [7]. The high amount of ferrous iron in the soil solution can also lead to an imbalance of mineral nutrients that affect plant growth. Ferrous iron that is absorbed by plants and concentrated in the leaves causes discoloration in the leaves, reduces the number of tillers and significantly reduces yield [10].

High soil Fe content also has an indirect effect on rice growth and yield, namely the availability of phosphorus (P). The availability of $\mathrm{P}$ is low in soils with high Fe content due to the fixation or retention of $\mathrm{P}$ by Fe. On acid soils (low $\mathrm{pH}$ ), soluble phosphate will react with soluble $\mathrm{Fe}$ and its hydrous oxides to form relatively less soluble Fe phosphate compounds. P fixation by $\mathrm{Fe}$ oxides decreases with increasing $\mathrm{pH}$. An increase in $\mathrm{pH}$ decreases Fe activity so that adsorption decreases and increases the concentration of soluble $\mathrm{P}[14]$.

Fe poisoning in rice occurs because soil with high Fe content in flooded conditions will dissolve iron as $\mathrm{Fe}^{2+}$ with high levels. The solubility can be $6,000-8,000 \mathrm{mg} \mathrm{kg}^{-1}$ [8]. At concentrations of $\mathrm{Fe}^{2+} 1,000-2,000 \mathrm{mg} \mathrm{kg}^{-1}$ can affect the production of lowland rice [9]. The critical limit of Fe stress that can be tolerated by rice plants is $250-500 \mathrm{mg} \mathrm{kg}^{-1}$. Furthermore, yield reduction due to Fe poisoning ranges from $50 \%[10]$.

Soils with high levels of Fe need special management to control the solubility of Fe in order not to reach the toxic limit and reduce the availability of $P$ for plants. Fe stress caused by high dissolved Fe can be reduced by: 1) adjusting the rhizosphere atmosphere so that it is not too reductive through intermittent water management and planting time of 14 days 
after inundation and (2) providing organic fertilizer with $\mathrm{C} / \mathrm{N}$ ratio $<25$ so that it has redox potential. does not drop to $<100 \mathrm{mV}$ [15]. With the macak-macak irrigation system with NPK (nitrogen, phosphor, potassium) fertilizer and 5 tons ha-1 of straw compost improved growth and increased rice yields $48.13 \%$, suppressed Fe uptake up to $81.02 \%$ in greenhouse experiments and $82.06 \%$ in field trials, reduced Fe toxicity by up to $85 \%$ in greenhouse experiments and $91.06 \%$ in field trials compared to continuous flooding [16].

Intermitten irrigation is widely reported to be able to overcome Fe poisoning in newly opened paddy fields. Intermittent irrigation treatment can reduce the rate of reduction of $\mathrm{Fe}$ and Mn, so that the solubility of Fe II and Mn II which can poison plants can be suppressed [17]. However, the application of interrupted irrigation treatment in the field must be carried out with caution, because in addition to toxic elements ( $\mathrm{Fe}$ and $\mathrm{Mn}$ ) are wasted, nutrients that are useful for plants $(\mathrm{N}, \mathrm{K}, \mathrm{Ca}$, and $\mathrm{Mg}$ ) are also wasted [18]. One of the efforts to overcome $\mathrm{Fe}$ poisoning can be done by water management by intermittent irrigation, namely during the rice planting season, waterlogging is not carried out continuously. If symptoms of Fe poisoning begin to appear, irrigation is stopped and the mapped water is immediately discarded. The mapped soil was allowed to dry a bit and then irrigated again. This drying may be carried out several times during the rice growing season [19]. Flooding neutralizes problem soils, where the $\mathrm{pH}$ is generally stable at around neutral $\mathrm{pH}(6.5$ - 7.5), and increases the availability of nutrients $\mathrm{N}$-ammonium, $\mathrm{P}, \mathrm{K}, \mathrm{Ca}, \mathrm{Mg}, \mathrm{Fe}$, $\mathrm{Mn}$ and Si. To reduce the $\mathrm{P}$ uptake, the $\mathrm{pH}$ was increased to about 5.5 and the absorption site was saturated with other competing anions, such as organic anions from decomposition of organic matter [20].

With the various problems faced, the cultivation of rice in new openings requires an adaptive technology package that can increase the productivity of new opened rice fields, one of which is the management of irrigation water.

\section{Methodology}

\subsection{Study sites and soil analysis}

The assessment was carried out on new wetland openings affected by iron toxicity in Muntuialo, Betara Subdistrict, West Tanjung Jabung District, Jambi from April to October 2018. Analysis of soil samples were conducted at the Bogor Soil Research Institute Laboratory. The analysis procedures are based on Technical Guidance on Soil, Plant, Water, and Fertilizer Chemical Analysis [21].

\subsection{Experimental set up and fertilization}

The study used a Randomized Block Design (RBD) with 4 (four) replications. The treatment consisted of water management: 1) Continuous iirigation (CI); 2) Dry wet irrigation (DWI) with 5-day intervals starting from 1 to 7 WAP (week after planting) (DWI1); 3) 7-day DWI interval from 1 to 7 WAP (DWI2); and 4) DWI until 65 days after planting and inundation 15 days before harvest (DBH)(DWI3).

Fertilizer recommendations based on soil nutrient status as a result of analysis with the Swamp Soil Test Kit (SSTK), namely 1.0 tonnes ha ${ }^{-1}$ lime, $75 \mathrm{~kg} \mathrm{ha}^{-1}$ Urea (basic fertilizer) then based on leave colour chart (LCC), $150 \mathrm{~kg} \mathrm{ha}^{-1} \mathrm{SP} 36$ (given entirely at planting time) and $125 \mathrm{~kg} \mathrm{ha}^{-1} \mathrm{KCl}(1 / 3$ part at planting, $1 / 3$ part at 3-4 WAP and $1 / 3$ part at plant age 6-7 WAP. Planting is done by transplanting with old seedlings 21 days as many as 2-3 stems clumps with the Jajar Legowo 4:1. 


\subsection{Plant planting and maintenance}

Implementation of field activities ranged from seed preparation to harvest and post-harvest refers to the Integrated Crop Management (ICM) approach consisting of labeled seeds, 20 day-old seeds, 3 seedlings per clump, legowo row planting system 4:1, Pest Control and ICM, and the harvest was carried out when the grain had yellowed 95\% (33-36 days after flowering) [22]. Observations were made on the soil chemical properties before the assessment, plant height, number of productive tillers, number of grains per panicle, and yields per hectare.

\subsection{Data analysis}

Data were analyzed using the MINITAB 15 application program for analysis of variance (ANOVA) [23]. If the treatments in ANOVA results had a significant difference, then the analysis was continued with Duncan's Multiple Range Test (DMRT) with a significant level of $5 \%$ [24].

\section{Results and discussion}

\subsection{Characteristics of soil nutrient status}

This new wetland openings in Muntialo Village was printed in 2017 covering an area of 30 ha, is a river path located between the higher land on the left and right. The results of the analysis of the chemical properties of paddy fields are as shown in Table 1.

Table 1. Results of topsoil analysis $(0-20 \mathrm{~cm})$ from Muntialo Village, Betara District, West Tanjung Jabung Regency

\begin{tabular}{|l|c|c|}
\hline \multicolumn{1}{|c|}{ Types of Value Analysis } & Value & Criteria \\
\hline $\mathrm{pH}(\mathrm{H} 2 \mathrm{O})$ & 3,75 & A biet sour \\
\hline $\mathrm{C}$-Organik (\%) & 3,55 & medium \\
\hline Organic Matter $(\%)$ & 5,25 & medium \\
\hline N-total $(\%)$ & 0,15 & low \\
\hline P-Potensial $\left(\mathrm{mg} \mathrm{P}_{2} \mathrm{O}_{5} 100 \mathrm{~g}^{-1}\right)$ & 11.50 & low \\
\hline $\mathrm{K}-$ Potensial $\left(\mathrm{mg} \mathrm{K}_{2} \mathrm{O} 100 \mathrm{~g}^{-1}\right)$ & 4,82 & low \\
\hline $\mathrm{Cu}$ available $(\mathrm{ppm})$ & 0,21 & low \\
\hline $\mathrm{Zn}$ available $(\mathrm{ppm})$ & 0,09 & low \\
\hline Fe available $(\mathrm{ppm})$ & 35,20 & high \\
\hline CEC of soil $\left(\mathrm{me} 100 \mathrm{gr}^{-1}\right)$ & 24,35 & medium \\
\hline
\end{tabular}

The results of the analysis of the chemical properties of the initial soil on the soil had a $\mathrm{pH}$ value of $3.75 \mathrm{H}_{2} \mathrm{O}$ (slightly sour) with a C-organic content of $3.55 \%$ of medium value. At this low $\mathrm{pH}$, the availability of $\mathrm{P}, \mathrm{K}$ and $\mathrm{Ca}$ elements is low, and the availability of available $\mathrm{Fe}$ is high $(35.20 \mathrm{ppm})$. The availability of $\mathrm{Cu}$ and $\mathrm{Zn}$ is low because it is hydroxylated to precipitate which is not available to plants. The CEC value of the soil is $24.35 \mathrm{cmol}^{(+)} \mathrm{kg}^{-1}$ with moderate value. Total soil $\mathrm{N}$ content $(0.11 \%)$, low potential $\mathrm{P}$ (11.50 mg $\mathrm{P}_{2} \mathrm{O}_{5} 100 \mathrm{~g}^{-1}$ ), also low potential $\mathrm{K}\left(4.82 \mathrm{mg} \mathrm{K}_{2} \mathrm{O} 100 \mathrm{~g}^{-1}\right)$.

High acidity with low soil $\mathrm{pH}$ has an impact on the solubility of iron and aluminum in the soil. This can cause the growth of plant roots to be disturbed. The varieties for lebak swamp are generally tolerant of acid soil conditions. In addition, the high solubility of iron 
and aluminum will directly affect the availability of nutrients, especially $\mathrm{P}$, so that $\mathrm{P}$ fertilization becomes inefficient.

The content of iron $\left(\mathrm{Fe}^{2+}\right)$, aluminum $\left(\mathrm{Al}^{3+}\right)$, hydrogen ion $(\mathrm{H}+)$, and sulfate $\left(\mathrm{SO}_{4}\right)$ in the drained area was higher than that of the non-drained area. This implies that after the land is reclaimed by building a drainage system and network, it will result in a decrease in the quality of the soil and water environment. The total $\mathrm{SO}^{2-}$ leached from the drained field was $3.34 \mathrm{~mol} \mathrm{~m}^{-2}$ year-1, which is equivalent to 1.17 moles of pyrite $\mathrm{m}-2$ year-1 or $140 \mathrm{~g}$ of pyrite $\mathrm{m}^{-2}$ year-1. On undrained fields, the total SO $4{ }^{2-}$ leached was 1.18 moles of pyrite $\mathrm{m}^{-2}$ year-1 which is equivalent to 0.59 moles of pyrite $\mathrm{m}^{-2}$ year- 1 or $71 \mathrm{~g}^{-1}$ pyrite $\mathrm{m}^{-2}$ year $^{-1}$ [25].

The results of the identification of the semi-detailed soil map of West Tanjung Jabung Regency with an updated version of 1:50,000 [11] and field verification showed that the soils found in West Tanjung Jabung Regency according to the National Soil Classification [26] consist 7 species consisted of: organosol, Alluvial, Cambisol, Gleisol, Nitosol, Podsolic and Oxisol [27].

The main effect of Fe poisoning in various regions can vary, Fe poisoning can occur in conditions of low $\mathrm{pH}$, high dissolved iron, low cation levels, low CEC or a combination of these factors [28]. Deficiency of macro elements, low supply of Mn, deficiency of K causes excessive absorption of $\mathrm{Fe}$ [29]. Nutrient-rich plants have greater ferrous $\left(\mathrm{Fe}^{++}\right)$oxidizing power in the soil than nutrient-deficient plants. Potassium deficiency has a major effect on the oxidizing strength of roots. This is in line with the frequent occurrence of plant responses to $\mathrm{K}$ fertilization on land with high Fe content [30]. Deficiency of $\mathrm{K}$ and $\mathrm{P}$ decreased the oxidation capacity of roots and accelerated the process of Fe poisoning, but $\mathrm{N}$ deficiency did not increase Fe uptake but high amounts of N stimulated Fe uptake.

Fe is a micro nutrient for plants, needed in small amounts, functions as an activator of enzyme systems, chlorophyll synthesis processes, and oxidation-reduction in respiration. Fe deficiency interferes with the mechanism for making chlorophyll and as a building block for certain enzymes and proteins [31]. In acid soils, microelements such as Fe can be dissolved and available to plants in abundance and often poison plants. The critical limit of Fe poisoning in plants is $300 \mathrm{ppm}$ [28].

The results of observations on the effect of water management on rice growth and production (Inpara 3) in new wetland openings affected by iron poisoning are presented in Table 2. There was no significant difference in the effect of several methods of water management on rice plant height. The highest plant height $(106.05 \mathrm{~cm})$ was obtained by water management by wet-dry irrigation (WDI) at 7-day intervals from 1 WAP to 7 WAP, followed by water management by Continuous irrigation until 65 DAP and inundation of 15 DAP $(100.73 \mathrm{~cm})$. Meanwhile, water management using Continous irrigation, 5 days interval starting from 1 WAP to 7 WAP $(99.85 \mathrm{~cm})$ and the lowest $(97.93 \mathrm{~cm})$ water management with continuous irrigation.

Table 2. Growth and production performance of Inpara 3 variety with several methods of water management.

\begin{tabular}{|c|c|r|r|r|r|r|}
\hline No. & $\begin{array}{c}\text { Water } \\
\text { management }\end{array}$ & $\begin{array}{c}\text { Plant heigh } \\
\text { (cm) }\end{array}$ & $\begin{array}{c}\text { Tiller } \\
\text { (clump) }\end{array}$ & $\begin{array}{c}\text { Productive } \\
\text { tiller } \\
\text { (clump) }\end{array}$ & $\begin{array}{c}\text { Grain per } \\
\text { panicle } \\
\text { (seed) }\end{array}$ & $\begin{array}{c}\text { Production } \\
\text { (t ha }^{-1} \text { ) }\end{array}$ \\
\hline 1. & CI & $97,93 \mathrm{a}$ & $19,41 \mathrm{a}$ & $13,58 \mathrm{a}$ & $86,41 \mathrm{a}$ & $2,22 \mathrm{a}$ \\
2. & DWI1 & $99,85 \mathrm{ab}$ & $24,67 \mathrm{~b}$ & $17,41 \mathrm{c}$ & $100,75 \mathrm{~b}$ & $3,98 \mathrm{~b}$ \\
3. & DWI & $106,05 \mathrm{bc}$ & $27,00 \mathrm{c}$ & $20,25 \mathrm{~d}$ & $122,25 \mathrm{c}$ & $4,29 \mathrm{~b}$ \\
4. & DWI3 & $100,73 \mathrm{ab}$ & $24,00 \mathrm{~b}$ & $16,17 \mathrm{~b}$ & $98,33 \mathrm{a}$ & $4,18 \mathrm{~b}$ \\
\hline
\end{tabular}

Note: CI (continuous irrigation), DWI (dry wet irrigation)

Water management by wet-dry irrigation (WDI) with 7-day intervals starting from 1 WAP to 7 WAP, showing the maximum number of tillers, the number of productive tillers, 
the number of grain per panicle and the results were significantly different from other water management. The yield obtained is 4.29 tons $\mathrm{ha}^{-1}$.

Symptoms of poisoning can occur in various phases of rice plant growth, both in the budding phase, pregnant and after the flowering period. In very severe conditions, root development is inhibited, the number of grains per panicle is low, as a result the yield will decrease. Based on the results of the study, iron poisoning in heavily attacked rice plants resulted in very poor growth, tillers did not grow so that the results obtained were very low and could even lead to crop failure [32].

In the research of Sukristiyonubowo [2], found that $3 \mathrm{~cm}$ inundation had a significant effect and increased the highest yield compared to other treatments on the number of tillers to the harvest and the production of grain yields for the Ciliwung variety of lowland rice. Sukristiyonubowo [33] intermittent inundation height of $5 \mathrm{~cm}$ (2 weeks inundated - 1 week dry) significantly increased the weight of fresh straw, weight of grain at harvest and weight of dry milled grain (14\% moisture content) when compared to other high inundation treatments. In addition, the provision of low puddel of water with a water level of $0.5 \mathrm{~cm}$ and intermittent with a puddle of $5 \mathrm{~cm}$ in the wet period each produced the best water productivity, namely 0.78 gram liter $^{-1}$ and 0.40 gram liter- 1 , respectively. also means that the treatment can save water approximately 32 to 172 x 105 liters of season-1 [2].

Interrupted irrigation can overcome iron poisoning in newly wetland openings. Treatment with intermittent irrigation can reduce the reduction of $\mathrm{Fe}^{+2}$ and $\mathrm{Mn}^{-2}$ which are toxic to plants [6]. Flooding and drying of paddy fields causes the reduction or oxidation of iron. In flooded conditions, ferrous iron $\left(\mathrm{Fe}^{3+}\right)$ is reduced to ferrous iron $\left(\mathrm{Fe}^{2+}\right)$ and vice versa in drying or oxidation conditions, ferrous iron $\left(\mathrm{Fe}^{2+}\right)$ quickly turns into ferrous iron $\left(\mathrm{Fe}^{3+}\right)$ without causing poisoning to plants.

Water management had a significant effect on the number of panicles per clump. Then the continuous water management provided fewer tillers per clump compared to WDI. According to Munarso [34], the number of panicles per clump is influenced by the genotype of the rice variety used. The potential number of productive tillers in this study as the number of panicles per clump is 14 to 17 panicles per clump while the results of this study have exceeded the potential number of panicles per clump according to the description of the Inpara 3 rice variety [35],.

Arrangement of drainage in paddy fields will improve the physical properties of the soil. In addition, the soil does not accumulate ferrous because it is carried away by the flow of water, so that ferrous is reduced in the soil. Alternating drying and flooding of paddy fields has a positive impact on the absorption of iron by plants. When the soil is dried, iron is in the form of ferric and cannot be absorbed by plants, the state becomes oxidative so that ferrous is oxidized to ferric. On the other hand, when the soil is flooded, iron is in the ferrous form and can be absorbed by plants. Thus, drying rice fields at the right time in the sense that it does not interfere with the growth of rice plants can reduce the level of iron poisoning.

According to Suriadikarta [36], intermittent irrigation has a positive effect. Effect of Water Management on Growth and Yield of Rice Plants in newly opened paddy fields the effect of iron poisoning [4] because drying will decrease the solubility of $\mathrm{Fe}^{+}$and the uptake of $\mathrm{P}, \mathrm{K}, \mathrm{Ca}$ and $\mathrm{Mg}$ plants increases.

\section{Conclusion and recomendation}

Characteristics of soil chemical properties of on new wetland openings of iron poisoning rice fields in the study site were slightly acidic $\mathrm{pH}$, moderate organic $\mathrm{C}$, high available $\mathrm{Fe}$ content, low availability of $\mathrm{N}, \mathrm{P}, \mathrm{K}, \mathrm{Ca}, \mathrm{Cu}$ and $\mathrm{Zn}$ elements, medium soil CEC. 
The water supply interval significantly affects the growth and production of rice, the highest yield is obtained with a 7 day water supply interval from 1 to 7 WAP, with rice production 4,29 tonnes $\mathrm{ha}^{-1}$, whereas with the provision of water from 1 WAP until just before harvest, the rice production was 2.06 tonnes $\mathrm{ha}^{-1}$.

Acknowledgements: The author would like to thank Ratna Rubiana, a Plant Pest Researcher and Rustan Hadi for their assistance as field technicians at the Jambi Assesment Institute Agricultural Technology (AIAT) and M. Taha as officers from the Jambi Province Food Crops and Horticultural Protection Agency.

\section{References}

1. Agus F, Wahyunto, and DJ Santoso, Recommendations for fertilizing paddy fields for new openings, New Opening Rice Fields [in Bahasa] (Indonesian Center for Agricultural Land Resources Research and Development, Indonesian Agency for Agricultural Research and Development, Indonesian Ministry of Agriculture, 2007).

2. Sukristiyonubowo, K. Nugroho, S. Ritung, Int. Res. J. Agric. Soils Sci. 2, 8, 328- 332 (2012)

3. Directorate General of Agricultural Infrastructure and Facilities, The expansion of new rice fields is one solution to increase the volume of domestic rice production [in Bahsa] (Directorate General of Agricultural Infrastructure and Facilities, Jakarta, 2013)

4. Christianto P.P., Suprihatin, I.G.P. Wigena, Effect of Water Management on Growth and Yield of Rice (Oryza Sativa L.) in New Opening Rice Fields. Proceedings of Scientific Works Concert, August 2016, Issn: 2460-5506 (2016)

5. Nursyamsi D., D. Setyorini, J. Sri Adiningsih, Nutrient management and drainage arrangements to overcome new rice field productivity constraints, in the Proceedings of the Discussion and Communication Meeting on the Results of Soil and Agroclimate Research, 26-28 September 1995, Cisarua, Bogor (1996)

6. Hartatik W., Sulaeman, A. Kasno, 2010, Changes in Soil Chemical Properties and Amelioration of New Opening Rice Fields, New Opening Rice Fields (Indonesian Center for Agricultural Land Resources Research and Development, Indonesian Agency for Agricultural Research and Development, Indonesian Ministry of Agriculture [In Bahasa] (2010)

7. Becker, M., F. Asch, J. Plant Nutr. Soil Sci. 168, 4, 558-573 (2005)

8. Patrick, W.H., C.N. Reddy, Chemical changes in rice soil (IRRI Los Banos, Philippines, 1978)

9. Asch, F., M. Becker, D.S. Kpongor, J. Plant Nutr. Soil Sci. 168, 6, 764-773 (2005)

10. Audebert A., Toxicity in rice-environmental condition and symptoms, In: Audebert. A.L.T. Narteh. D. Millar and B. Beks, Iron Toxicity in Rice- Based System in West Africa, (Africa Rice Center, WARDA, 2006)

11. Indonesian Agency for Agricultural Research and Development, Semi-detailed Land Map of West Tanjung Jabung Regency 1:50,000 Scale updated version (Indonesian Center for Agricultural Land Resources Research and Development, Indonesian Agency for Agricultural Research and Development [In Bahasa] (2016)

12. Majerus V., P. Bertin, S. Lutts, Plant Sci. 173, 2, 96-105 (2007)

13. Majerus V., P. Bertin, S. Lutts, Plant Sci. 173, 2, 96-105 (2007)

14. Munawar, A., Soil Fertility and Plant Nutrition (IPB Press, Bogor, 2011)

15. Maas, A., Techology to anticipate abiotic stress in rice cultivation, in Proceeding of the Scientific Seminar on National Rice Research Results, Indonesian Center for Rice Research, AARD, 27-28 July 2011, Sukamandi, Indonesia (2011)

16. Syafruddin, J. Agribus. Reg. Dev. 3, 1 (2011) 
17. Yusuf, A., S. Djakamiharja, G. Satari, S. Djakasutami, Effect of soil $\mathrm{pH}$ and Eh on the solubility of $\mathrm{Fe}, \mathrm{AI}$, and $\mathrm{Mn}$ in newly opened rice fields of Oxisol type, in the Proceedings of the Management of New Opening Rice Fields to Support Food SelfSufficiency and the Transmigration Program, 17-18 September 1990, Padang, Indonesia (1990)

18. Widowati, L.R., D. Nursyamsi, J. Sri Adiningsih, J. Soil and Clim. 15, 50-60 (1997)

19. Kasim, M., Water use management: minimizing water use to increase lowland rice production through the system of rice intensification (SRI), in Inaugural Speech as Permanent Professor in the Field of Plant Physiology at the Faculty of Agriculture, Andalas University [In Bahasa] (2004)

20. Sahrawat, K.L., ICRISAT 58, 4, 423-436 (2012)

21. Eviati, Sulaeman, Petunjuk Teknis Analisis Kimia Tanah, Tanaman, Air dan Pupuk (IAARD, 2012)

22. Indonesian Agency for Agricultural Research and Development, Integrated Crop Management (ICM) for Lebak Swamp Rice, in The Guidelines for Agricultural Extension in Suyamto, H Pane, Suwarno, B Kustianto, AK Makarim, H Suharso and H Sembiring, eds. (Indonesian Agency for Agricultural Research and Development, Indonesian Ministry of Agriculture, 2007)

23. Syukri MN, Minitab 15 Program Application: Statistics for Experimental Design [in Bahasa] (PT. Calprint Indonesia, 2009)

24. Steel RGD, IH Torrie, Statistical Principles and Procedures: A Biometric Approach (Translated by: B. Sumantri) [in Bahasa] (PT. Gramedia, Jakarta, 1991)

25. Konsten, C.J.M., S. Suping, I.B. Aribawa, and IPG. Wijaya Adhi, Chemical Proses In Acid Sulphate Soil In Pulau Petak South and Central Kalimantan Indonesia, in Papers Workshop on Acid Sulphate Soils in the Humid Tropic, 20-22 November 1990, Bogor, Indonesia (1990)

26. Subardja, D. S., S. Ritung, M. Anda, Sukarman, E. Suryani, R. E. Subandiono, National Soil Classification Technical Guidelines [in Bahasa] (Indonesian Center for Agricultural Land Resources Research and Development, Indonesian Agency for Agricultural Research and Development, Indonesian Ministry of Agriculture, 2016)

27. Indonesian Agency for Agricultural Research and Development, Key Soil Taxonomy (Indonesian Center for Agricultural Land Resources Research and Development, Indonesian Ministry of Agriculture, 2016)

28. Suhartini. T., Germplasm Bulletin 10, 1 (2004)

29. Ismunadji, M., W.S. Ardjasa, H.R. von Uexkull, Increasing productivity of lowland rice grown on iron toxic soil, Paper presented at International Symposium on Rice production on Acid Soils of tropics, June 26-30, 1989, Kandy, Sri Lanka (1989)

30. Makarim, K., O. Sudarman, H. Supriadi, Agric. Res. 9, 4, 166-170 (1989)

31. Brady, N.C. 1974, The nature and properties of soils (Macmilan Publishing Co. Inc., New York, 1974)

32. Khairullah, I., D. Indradewa., P. Yudono, A. Maaz, J. Agrosci. 18, 2 (2011)

33. Sukristiyonubowo, Research and Development of Land and Water Management Technology to Accelerate Improvement and Stability of New Opening Rice Field Productivity in East Kalimantan and West Sumatra $>40 \%$ [Final Report of the Applied Research Incentive Program] (Indonesian Soil Research Institute, 2010)

34. Munarso, Y.P., J. Agron. Indonesia 39, 3, 147-152 (2011)

35. Indonesian Center for Rice Research, Description of Inpara 3, http://www.litbang. Agriculture.go.id/varietas/Ciherang (2015)

36. Suriadikarta, D.A., W. Hartatik, Nutrient Management Technology for New Opening Rice Fields (Indonesian Soil Research Institute, 2004) 